\title{
Brassica elongata ssp. integrifolia seed germination
}

\author{
JAMES A. YOUNG, CHARLIE D. CLEMENTS, AND ROBERT WILSON
}

Authors are Range Scientists, USDA, ARS, Exotic and Invasive Weed Management, 920 Valley Road, Reno, Nev. 89512, and Extension Educator, University of Nevada, 995 Compton St. Ely, Nev. 89310.

\begin{abstract}
Repeatedly during the late $19^{\text {th }}$ and early $20^{\text {th }}$ century, exotic weeds were introduced to the sagebrush (Artemisia)/bunchgrass rangelands of the Great Basin. Once established these weeds became invasive, spreading without the conscious efforts of humans. Brassica elongata ssp. integrifolia (Boiss.) Breistr. offers evidence this process of introduction still continues. Brassica elongata ssp. integrifolia is native to southeastern Europe and Asia. It was first collected in North America near Portland, Ore. in 1911. This initial infestation apparently did not persist. The next collection was near Eureka, Nev. in 1968. Currently, Brassica elongata ssp. integrifolia has spread about $200 \mathrm{~km}$ east and west along $U S$ Highway 50 and $100 \mathrm{~km}$ north and south of the highway along secondary roads. As a first step in understanding the seed and seedbed ecology of this new invasive weed we investigated the germination of seeds at a wide range of constant and alternating temperatures. This plant produces abundant seeds that germinate over a wide range of constant and alternating temperatures. Maximum germination ranged from 84 to $94 \%$ depending on the year of seed production. Germination was extremely limited at very cold seedbed temperatures and low at the cold category of seedbed temperatures. Germination at these temperature is a competitive advantage for other exotic species on Great Basin rangelands.
\end{abstract}

Key Words: exotic weed, seedbed ecology, germination temperatures

Exotic weeds on rangelands are a cause of considerable concern because of the economic losses and ecological damage these species can produce. Recently, the exotic annual cheatgrass (Bromus tectorum L.) has provided fuel for huge wildfires in the Great Basin (Young et al. 1987). During the 1940s and 1950s, there was widespread alarm over the spread of the toxic exotic species halogeton (Halogeton glomeratus [M. Bieb.] C. Meyer) because of its destructive influence on the range sheep industry (Young et al. 1999). Brassica elongata ssp. integrifolia (Boiss.) Breitr. is proof that these endless cycles of introduction and spread are not complete (Young et al. 2003).

According to Flora Europea, Brassica elongata is native to southeastern Europe and Asia (Tutin et al. 1964). In Asia, it is found in southern Russia, the Ukraine, and the Republics of Central Asia as well as Turkey and Iran. In Asia, B. elongata occurs in semi-arid environments very similar to the sagebrush (Artemisia) zone environments of the Great Basin. There are 2

The corresponding author is Young (jayoung@scs.unr.edu).

Manuscript accepted 4 Feb. 02
Resumen

A fines del siglo 19 e inicios del siglo 20, en forma repetida, se introdujeron malezas exóticas a los pastizales de "Sagebrush" (Artemisia)/zacates amacollados de la Gran Cuenca. Una vez establecidas estas malezas vienen a ser invasoras, diseminandose si esfuerzos concientes del hombre. La especie Brassica elongata ssp. integrifolia (Boiss.) Breistr. ofrece evidencia de que este proceso de introducción aun continua. Brassica elongata ssp. integrifolia es nativa del sudeste de Europa y Asia, en Norteamérica fue colectada por primera vez en 1911 cerca de Portland, Ore., esta infestación inicial aparentemente no persistió; La siguiente colección fue cerca de Eureka, Nev. en 1968. Actualmente Brassica elongata ssp. integrifolia se ha diseminado $200 \mathrm{~km}$ al este y oeste a lo largo de la autopista US 50 y $100 \mathrm{~km}$ al norte y sur de la autopista a lo largo de caminos secundarios. Como un primer paso para entender la ecología de la semilla y de la cama de siembra de esta nueva especie de maleza invasora investigamos la germinación de la semilla en un amplio rango de temperaturas constantes y alternantes. Esta planta produce abundante semilla que germina en un amplio rango de temperaturas constantes y alternantes. La máxima germinación varió de 84 a 94\%, dependiendo del año en que se produjo la semilla. La germinación fue extremadamente limitada en camas de siembra con temperaturas muy frías y baja en temperaturas catalogadas como frías. La germinación a estas temperaturas es una ventaja competitiva para otras especies exóticas en los pastizales de la Gran Cuenca.

subspecies of this weed in its native distribution. The European form has divided to the mid-rib leaves and is known as B. elongata ssp. elongata Ehrh. Most species of Brassica that have established as exotic weeds in North America have basal leaves that are pinnatifid and leaves on the stem that are dentate (Munz and Keck 1959). The subspecies elongata was first described from specimens collected in Hungary (Rollins 1980). The plant that was introduced to Nevada is B. elongata ssp. integrifolia (Boiss.) Breistr., the subspecies from the semi-arid regions of Asia. The basal leaves of this subspecies are entire.

Brassica elongata was first collected in the United States in 1911 by Wilhelm Suksdorf at Linnton near Portland, Ore., in an area where ballast was unloaded from ships (Rollins 1980). We are not sure in which subspecies the Oregon collection belonged. This population apparently did not survive and the plant was considered to not occur in North America. In 1968 the noted American botanist John Thomas Howell was driving across central Nevada on U S Highway 50. He noted a plant in flower along the highway west of Pancake Summit in Eureka County (Rollins 1980). This specimen was deposited in the Gray Herbarium, misidentified as Thelypodium (Rollins 1980). 
Based on herbarium specimens listed by Rollins (1980), and those housed at the University of Nevada Herbarium, and our own surveys, the current distribution of Brassica elongata is from Antelope Valley in Eureka County, east along U S Highway 50 for $200 \mathrm{~km}$. It extends north and south of the highway along secondary roads for $100 \mathrm{~km}$. The infestations are to the best of our knowledge restricted to roadsides. The plants are well established in portions of the road right-of-ways where native secondary successional species such as rabbitbrush (Chrysothamnus sp.) and squirreltail (Elymus elymoides [Raf.] Swezey) exist, indicating soil disturbance has not occurred for several years. The remarkable part of this distribution is the rugged topography and variety of plant communities it encompasses. The valley floor where the original collection was made is $1846 \mathrm{~m}$ in elevation with salt affected soils and 150 to $200 \mathrm{~mm}$ of highly variable annual precipitation. To the east along Highway 50 an infestation occurs at 2320 $m$ elevation where the highway passes through pinyon (Pinus monophylla Torr. \& Frem.)/juniper (Juniperus osteosperma [Torr.] Little) woodlands with mountain big sagebrush (Artemisia tridentata subspecies vaseyana [Rydb.] Beetle) in openings in the woodland.

Our purpose is to investigate the seed germination of Brassica elongata ssp. integrifolia at a wide range of constant and alternation incubation temperatures. This will give some understanding of the possible range of adaptation of this species.

\section{Methods}

We collected seeds in 1999 from a population of Brassica elongata growing along Highway 50 in the upper portion of Copper Flat in White Pine County, Nev. (Latitude N. $39^{\circ} 00^{\prime}$ Longitude W. $115^{\circ}$ $\left.30^{\prime}\right)$. The elongated stand covers about 2 ha. Seeds were collected from about 100 plants. In 2000, seeds were collected from a much larger population in Newark Valley, Eureka County on the road to the Fish Creek Ranch (Latitude $39^{\circ} 00^{\prime}$ Longitude $114^{\circ} 30^{\prime}$ ). This is probably an extension of the stand where John Thomas Howell made his original collection.

In all experiments 4 replications of 25 seeds each were used in a randomized block design. Seeds were placed on top of non-toxic commercial germination paper in closed Petri dishes and kept wet with tap water. Germination trials were conducted in the dark. Seeds were considered germinated when the radical emerged 1 $\mathrm{mm}$. Germination counts were made after 1,2 , and 4 weeks. Constant incubation temperatures were 0,2 , and $5^{\circ} \mathrm{C}$ and at 5 degree increments through $40^{\circ} \mathrm{C}$. Alternating regimes included 16 hours at each constant temperature, plus 8 hours at each possible higher temperature per 24 hours. For example, $35^{\circ} \mathrm{C}$ alternated with $40^{\circ} \mathrm{C}$ only, while $0^{\circ} \mathrm{C}$ alternated with 2 , $5,10,15,20,25,30,35$, and $40^{\circ} \mathrm{C}$. This made a total of 55 constant and alternating temperature regimes (Young et al. 1991).

The germination responses of the accessions of Brassica elongata were compared using the following seedbed temperature regime definitions (Young and Evans 1982): a. Very cold: $0 / 0$ (constant $\left.0^{\circ} \mathrm{C}\right), 0 / 2\left(0^{\circ}\right.$ $\mathrm{C}$ for 16 hours and $2^{\circ} \mathrm{C}$ for 8 hours in each 24hours), $0 / 5$ and $2 / 2^{\circ} \mathrm{C}$.

b. Cold: $0 / 10,0 / 15,2 / 5,2 / 10,2 / 15,5 / 5$, and $5 / 10^{\circ} \mathrm{C}$.

c. Cold fluctuating: $0 / 20$ through $0 / 40^{\circ}$ $\mathrm{C}$ and $2 / 20$ through $2 / 40^{\circ} \mathrm{C}$.

d. Fluctuating: $5 / 35$ through $5 / 40^{\circ} \mathrm{C}$, $10 / 35,10 / 40$, and $15 / 40 \mathrm{C}$.

e. Moderate: $5 / 20$ through $5 / 30,10 / 10$ through $10 / 30^{\circ} \mathrm{C}, 15 / 15$ through $15 / 35^{\circ}$ C, $20 / 20$ through $30 / 35^{\circ} \mathrm{C}$, and $25 / 25$ through $25 / 30^{\circ} \mathrm{C}$.

f. Warm: $20 / 40,25 / 35$, and $25 / 40^{\circ} \mathrm{C}$, $30 / 30$ through $30 / 40^{\circ} \mathrm{C}, 35 / 35,35 / 40$, and $40 / 40^{\circ} \mathrm{C}$.

The temperature categories reflect germination environments of field seedbeds based on several years of monitoring in the Great Basin (Evans et al. 1970, Evans and Young 1970, 1972).

Data from each base temperature and its alternating temperature regimes were used to generate a quadratic response surface with estimated means and confidence intervals at the $1 \%$ level of probability (Young et al. 1980, Evans et al. 1982, Palmquist et al. 1987). A number of germination parameters were calculated from the quadratic response surfaces (Table 1) (Young and Evans 1982).

\section{Results and Discussion}

There were marked differences as well as similarities in the germination profiles for the seeds of Brassica elongata collected in different years (Tables 2, 3, and 4). The seeds were not collected from the same stand because the population used in

Table 1. Germination parameters calculated from quadratic response surfaces (Young and Evans 1982).

\begin{tabular}{|c|c|c|}
\hline Calculated parameters & Derivation of parameter & Purpose \\
\hline $\begin{array}{l}\text { Calculated within profile: } \\
\text { Mean germination }\end{array}$ & Sum divided by 55 & Gross comparison of profiles \\
\hline Percentage of regimes with germination & Number with germination divided by 55 & Indication of breath of germination response \\
\hline Percentage of regimes with optima & $\begin{array}{l}\text { Number of regimes with germination not } \\
\text { less than the maximum observed minus } \\
\text { one half the confidence interval divided } \\
\text { by } 55\end{array}$ & $\begin{array}{l}\text { Provides indication of the breath of } \\
\text { temperatures that support optimum germination }\end{array}$ \\
\hline Mean of optima & $\begin{array}{l}\text { Sum of optima divided by number of } \\
\text { regimes with optima }\end{array}$ & $\begin{array}{l}\text { Provides a measure of potential germination at } \\
\text { most desirable temperatures }\end{array}$ \\
\hline Maximum germination & Highest observed germination & Indication of potential viability \\
\hline \multicolumn{3}{|l|}{ Calculated among germination profiles } \\
\hline Frequency of optima & $\begin{array}{l}\text { Times a given temperature supports } \\
\text { optimum germination divided by the } \\
\text { total number of test }\end{array}$ & $\begin{array}{l}\text { Provides an estimate of optimum temperatures } \\
\text { for germination with precision }\end{array}$ \\
\hline
\end{tabular}


Table 2. Mean germination of seeds of Brassica elongata \pm one half of the confidence interval at the 0.01 level of probability. Incubation for 4 weeks at a wide range of constant and alternating temperatures. Seeds produced in $1999{ }^{1}$

\begin{tabular}{|c|c|c|c|c|c|c|c|c|c|c|}
\hline \multirow{2}{*}{ Cold period temperature } & \multicolumn{10}{|c|}{ Warm period temperature $C$} \\
\hline & 0 & 2 & 5 & 10 & 15 & 20 & 25 & 30 & 35 & 40 \\
\hline (C) & & & & & 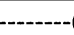 & $\cdots$ & -.- & -9--' & $\cdots$ & -....... \\
\hline 0 & $0+10$ & $0+10$ & $0+10$ & $0+10$ & $2 \pm 8$ & $10 \pm 8$ & $24 \pm 6$ & $26 \pm 8$ & $16 \pm 8$ & $0+10$ \\
\hline 2 & & $0+10$ & $0+10$ & $0+10$ & $7 \pm 8$ & $26 \pm 8$ & $33 \pm 8$ & $56 \pm 8$ & $34 \pm 10$ & $0+10$ \\
\hline 5 & & & $0+10$ & $2 \pm 8$ & $2 \pm 8$ & $9 \pm 10$ & $28 \pm 10$ & $61 \pm 4$ & $42 \pm 6$ & $0+10$ \\
\hline 10 & & & & $9 \pm 10$ & $18 \pm 8$ & $14 \pm 6$ & $44 \pm 4$ & $43 \pm 3$ & $29 \pm 8$ & $0+10$ \\
\hline 15 & & & & & $15 \pm 8$ & $25 \pm 8$ & $43 \pm 6$ & $68 \pm 8$ & $66 \pm 6$ & $34 \pm 6$ \\
\hline 20 & & & & & & $48 \pm 8$ & $64 \pm 6$ & $56 \pm 6$ & $65 \pm 6$ & $40 \pm 10$ \\
\hline 25 & & & & & & & $64 \pm 6$ & $67 \pm 8$ & {$[84 \pm 9]^{*}$} & $40 \pm 10$ \\
\hline 30 & & & & & & & & $18 \pm 10$ & $22 \pm 8$ & $16 \pm 8$ \\
\hline 35 & & & & & & & & & $5 \pm 8$ & $5 \pm 11$ \\
\hline 40 & & & & & & & & & & $0+10$ \\
\hline
\end{tabular}

Table 3. Mean germination of seeds of Brassica elongata \pm one half the confidence interval at the 0.01 level of probability. Incubation for 4 weeks at a wide range of constant and alternating temperatures. Seed produced in $2000{ }^{1}$

\begin{tabular}{|c|c|c|c|c|c|c|c|c|c|c|}
\hline \multirow{2}{*}{ Cold period temperature } & \multicolumn{10}{|c|}{ Warm period temperature $\mathrm{C}$} \\
\hline & 0 & 2 & 5 & 10 & 15 & 20 & 25 & 30 & 35 & 40 \\
\hline (C) & & & & & (c) & & & & & \\
\hline 0 & $0+12$ & $0+12$ & $1 \pm 10$ & $27 \pm 8$ & $45 \pm 6$ & $62 \pm 6$ & $66 \pm 6$ & $32 \pm 6$ & $32 \pm 6$ & $0+10$ \\
\hline 2 & & $0+12$ & $1 \pm 10$ & $3 \pm 10$ & $20 \pm 8$ & $40 \pm 8$ & $77 \pm 6$ & $70 \pm 6$ & $58 \pm 6$ & $2 \pm 10$ \\
\hline 5 & & & $2 \pm 10$ & $6 \pm 10$ & $31 \pm 8$ & $60 \pm 8$ & $71 \pm 6$ & $78 \pm 4$ & $66 \pm 6$ & $2 \pm 10$ \\
\hline 10 & & & & $5 \pm 8$ & $27 \pm 8$ & $54 \pm 8$ & $65 \pm 6$ & $66 \pm 6$ & $68 \pm 6$ & $10 \pm 8$ \\
\hline 15 & & & & & $68 \pm 6$ & {$[94 \pm 6 *$} & $94 \pm 6]^{*}$ & $86 \pm 6$ & $86 \pm 6$ & $23 \pm 8$ \\
\hline 20 & & & & & & $62 \pm 6$ & $67 \pm 6$ & $58 \pm 8$ & $58 \pm 8$ & $38 \pm 8$ \\
\hline 25 & & & & & & & $74 \pm 6$ & $66 \pm 6$ & $59 \pm 8$ & $59 \pm 8$ \\
\hline 3 & & & & & & & & $9 \pm 6$ & $15 \pm 8$ & $21 \pm 10$ \\
\hline 35 & & & & & & & & & $2 \pm 10$ & $20 \pm 10$ \\
\hline 40 & & & & & & & & & & $0+12$ \\
\hline
\end{tabular}

${ }^{1}$ Number following the mean is one half of the confidence interval as determined from regression equations used to develop the response surface (Palmquist et al. 1987). The maximum calculated germination is enclosed by brackets [ ]. * indicates means not lower than the maximum germination minus one half of its confidence interval, our definition of optimum germination.

1999 did not produce sufficient seeds in 2000. The collection sites were located within $30 \mathrm{~km}$ of each other, but had a difference of $430 \mathrm{~m}$ in elevation, with the 2000 collection being the lower site. For both collections, none of the seeds germinated at very cold incubation temperatures. In the Great Basin, precipitation generally occurs in the winter when temperatures are too cold for plant growth. Generally, the seeds of successful exotic species have the potential to germinate at very cold seedbed temperatures and this has been interpreted as evidence of a competitive advantage over seeds of many native species (i.e. Young and Evans 1977). There also were marked differences between the collections of Brassia elonga$t a$ in germination at cold, cold fluctuating, and moderate temperatures (Table 4). Only at moderate and warmer temperatures was the average germination similar for the 2 collections.

From an over all view point, the seeds of Brassica elongata have some germination at a remarkably broad spectrum of temperatures ( 76 to $94 \%$ of the 55 temperature regimes tested, Table 2). The maximum germination of 84 to $94 \%$ that was observed indicates the seeds have a high potential to germinate with little dormancy at optimum temperatures for germination. The populations we sampled differed in

temperatures that supported optimum germination (Table 4). The high elevation population had $84 \%$ germination at $25 / 35^{\circ}$ $\mathrm{C}\left(25^{\circ} \mathrm{C}\right.$ for 16 hours and $35^{\circ} \mathrm{C}$ for 8 hours in each 24 hours). The lower elevation population had $94 \%$ germination at $15 / 20$ and $15 / 25^{\circ} \mathrm{C}$.

Table 4. Germination parameters (standard error at the 0.01 level of probability) calculated from germination profiles for seeds of Brassica elongata collected in 1999 and 2000.

\begin{tabular}{lcc}
\hline \hline Germination parameter & \multicolumn{2}{c}{ Year seed produced } \\
& 1999 & 2000 \\
\hline & $-10 \pm 2.3$ & $30 \pm 3.1$ \\
Profile mean & $76 \pm 4.1$ & $93 \pm 4.9$ \\
Regimes with some germination & $84 \pm 5.1$ & $94 \pm 2.1$ \\
Mean of optima & $2 \pm 2.1$ & $4 \pm 2.3$ \\
Regimes with optima & $84 \pm 5.1$ & $94 \pm 3.7$ \\
Maximum germination & & \\
Seedbed temperature categories & 0 & 0 \\
$\quad$ Very cold & $1 \pm 4.1$ & $13 \pm 4.7$ \\
Cold & $23 \pm 5.1$ & $45 \pm 4.9$ \\
Cold fluctuating & $21 \pm 3.4$ & $34 \pm 4.0$ \\
Fluctuating & $27 \pm 2.6$ & $28 \pm 3.8$ \\
Warmer & $45 \pm 6.1$ & $61 \pm 3.9$ \\
Moderate & &
\end{tabular}


There is nothing in the temperature-germination profiles that is severely limiting except for the lack of germination at very cold temperatures. We have no idea where the species was first introduced in east central Nevada. The original collection site is on the far western side of the current known distribution. The distribution to the east and south is into a region where summer precipitation from monsoonal storms is consistent enough that it is probably much more biologically effective than further west in the Great Basin. The current known distribution of Brassica elongata may reflect the distribution of summer precipitation.

The area where this exotic species is now found contains irrigated farms where quality grass hay is produced for horses and it has been widely marketed in the western United States. As range and weed control scientist and technicians become more aware that Brassica elongata is established in the Great Basin, its range in western North America will be better known.

It is probably too late to eradicate this new exotic species, but existing populations could be greatly suppressed by weed control and revegetation programs. Many land management and agricultural people downplay the potential significance of this relatively new exotic species because it is largely confined to roadside environments. If you look back at the serious exotic, invasive weed species on the western range, it is easy to document references that virtually all exotic species were at one time confined to roadside environments. The roadside environment provides a temporary habitat while the exotic species evolves adaptation to its new environment.

\section{Literature Cited}

Evans, R. A. and J. A. Young. 1970. Plant litter and establishment of alien annual species in rangeland communities. Weed Sci. 18:697-703.

Evans, R. A. and J. A. Young. 1972. Microsite requirements for establishment of alien annual species in rangeland communities. Weed Sci. 20:350-356.

Evans, R. A., D. A. Easi, D. N. Book, and J. A. Young. 1982. Quadratic response surface analysis of seed germination trials. Weed Sci. 30:411-416.

Evans, R. A., H. R. Holbo, R. E. Eckert, Jr., and J. A. Young. 1970. Functional environment of downy brome communities in relation to weed control and revegetation. Weed Sci. 18:154-162.

Munz, P. A. and D. D. Keck. 1959. A California Flora. Univer. California Press, Berkeley, Calif.

Palmquist, D. E., R. A. Evans, and J. A. Young. 1987. Comparative analysis of temperature response surfaces. pp. 97-103 In G. W. Frasier and R. A. Evans (eds.) Seed and Seedbed Ecology of Rangeland Plants. USDA, Agr. Res. Ser., Washington, D. C.

Rollins, R. C. 1980. Another cruciferous weed Brassica elongata establishes itself in North America. Contributions Gray Herbarium 210:1-3.

Tutin, T. G., V. H. Heywood, N. A. Burges, D. H. Valentine, S. M. Walters, and D. A. Webb. 1964. Flora Europaea. Cambridge Univer. Press, Cambridge, U.K.

Young, J. A. and R. A. Evans. 1977. Germination requirements as determinants of species composition of sagebrush range communities. Proc First International Rangeland Congress, Soc. For Range Manage., Denver, Colo. pp. 366-369.

Young, J. A. and R. A. Evans. 1982. Temperature profiles for germination of cool season grasses. ARR-W-72, USDA, ARS, Oakland, Calif. 92 p.
Young, J. A., C. D. Clements, and R. Wilson. 2003. A new exotic weed on Great Basin rangelands. Rangelands (in press)

Young, J. A., R. A. Evans, R. E. Eckert, Jr., and B. L. Kay. 1987. Cheatgrass. Rangelands 9:266-270.

Young, J. A., D. E. Palmquist, and R. A. Evans. 1991. Temperature profiles for germination of big sagebrush seeds from native stands. J. Range Manage. 44:385-390.

Young, J. A., B. L. Kay, H. George, and R. A. Evans. 1980. Germination of three species of Atriplex. Agronomy J. 72:705-709.

Young, J. A., P. C. Martinelli, R. E. Eckert, Jr., and R. A. Evans. 1999. Halogeton. Misc. Publ. 1553. USDA, ARS, Washington, D. C. 